\title{
Evaluation of the Dressing Percentage of 3-year-old Experimental Scaly Crossbreds of the Common Carp (Cyprinus carpio, Linnaeus 1758) in Relation to Sex
}

\author{
H. BUCHTOVÁ ${ }^{1}$, Z. SVOBODOVÁ ${ }^{1,2}$, M. KOCOUR ${ }^{2}$, J. VELÍŠEK ${ }^{3}$ \\ ${ }^{1}$ University of Veterinary and Pharmaceutical Sciences, Brno, Czech Republic \\ 2 Joint Laboratory of Genetics, Physiology and Reproduction of Fish, Institute of Animal Physiology and \\ Genetics, Czech Academy of Science, Liběchov, and University of South Bohemia, Research Institute of Fish \\ Culture and Hydrobiology, Vodňany, Czech Republic \\ ${ }^{3}$ University of South Bohemia Ceské Budějovice, Faculty of Agriculture, Czech Republic \\ Received October 24, 2005 \\ Accepted March 16, 2006
}

\begin{abstract}
Buchtová H., Z. Svobodová, M. Kocour, J. Velíšek: Evaluation of the Dressing Percentage of 3-year-old Experimental Scaly Crossbreds of the Common Carp (Cyprinus carpio, Linnaeus 1758) in Relation to Sex. Acta Vet. Brno 2006, 75: 123-132.

The aim of the present study was to compare dressing percentages, with relation to sex, of three bisexual groups of hybrid carp, i.e. Hungarian mirror carp and Northern mirror carp (M2 $\times$ M72), the hybrid line of Přerov scaly carp and Northern mirror carp (PS $\times$ M72), the hybrid line of Přerov scaly carp and Ropsha scaly carp (PS $\times$ ROP), and the pure line of Přerov scaly carp (PS) in harvest size $\left(\mathrm{K}_{3}\right)$. There were practically no differences in growth variables of male and female carp between the pure line PS carp and M2 $\times$ M72 and PS $\times$ ROP hybrids. Statistically significant differences in some variables between sexes were found in the scaly hybrid line PS $\times$ M72. Females in that group had significantly higher growth rates (TL and SL by $4.08 \%$ and $4.52 \%$, respectively; $p<0.05$ ), and their weight variables were also higher (FW, CW and FilletW $\mathrm{Fbs}_{\text {by }} 11.37 \%, 13.70 \%$ and $14.83 \%$, respectively; $p<0.05$ and $p<0.01$ ). The weight of gonads of male carp from all the groups studied was significantly higher $(p<0.01)$ than that of ovaries of female carp (or, rather, the GSI of male carp was higher).

Carp, female, male, growth, weight, dressing percentage, gonadosomatic index
\end{abstract}

The common carp (Cyprinus carpio L.) is an important freshwater fish raised for food in aquaculture all over the world. In the Czech Republic, carp production makes up about 85\% of all freshwater fish farmed annually. Almost $50 \%$ of the carp produced is exported to the EU internal market under the Czech carp trademark (registered on 22 Oct. 2001 in the Czech Trademark Registry).

In practice, high-yield carp that are the result of special breeding programmes are primarily used for commercial carp farming. A review of various technologies used in the study of different fish species has been published by Hulata (2001).

Fish breeding in the Czech Republic is carried out on the facilities of the Czech Fishing Association under the supervision of the Research Institute of Fish Culture and Hydrobiology of the University of South Bohemia in České Budějovice (VURHJU CB). In experiments performed on the facilities, various types of hybridization crossing (Gela and Linhart 2000; Linhart et al. 2002; Hartvich et al. 2003; Kocour et al. 2003; Gela et al. 2003; Kocour et al. 2005ab), genome manipulations (Flajšhans et al. 1993ab; Flajšhans 1997; Flajšhans and Linhart 2000), and, in some cases, selection methods are used to improve yield variables of fish. These methods of breeding are not generally successful in carp because their growth patterns are not affected by the additive effects of genes (Moav and Wohlfarth 1976). Neither have the genome manipulation techniques produced unequivocally positive results in carp growth rate experiments (Cherfas et al. 1994; Flajšhan s et al. 1994).

\footnotetext{
Address for correspondence:

MVDr. Hana Buchtová, Ph.D.

University of Veterinary and Pharmaceutical Sciences Brno

Department of Meat Hygiene and Technology

Palackého 1-3

61242 Brno, Czech Republic
}

Phone: +420-541-562-742

Fax: +420-541-321-230

E-mail: buchtovah@vfu.cz

http://www.vfu.cz/acta-vet/actavet.htm 
Various types of hybrid (top, diallel, reproduction, combination) crossing, on the other hand, have produced some very good results, as evidenced by, e.g., growth rate tests performed regularly for newly bred hybrids of F1 generations and their parents throughout their life until they reach harvest maturity (Duda et al. 1999; Gela and Linhart 2000; Gela et al. 2003; Kocour et al. 2005a). Not even in these cases, however, heterosis will necessarily have a positive effect on the growth potential of the progeny of all the hybrids tested.

In practical terms, the volume of freshwater fish production on a commercial farm will also be influenced by a number of other factors (e.g. the composition and density of fish stock, health and welfare of the fish, use of suitable feeding patterns and feeds with an optimum composition of nutrients, essential nutrients, minerals and vitamins, geographical location and quality of the environment). An increase in production can be achieved by purposefully farming only one of the sexes, which is particularly true about fish species characterized by a large degree of sexual dimorphism (Tinca tinca) (Flajšhans et al. 1993ab; Bu chtová et al. 2003ab). In other fish species, the farming of only one of the sexes can be recommended only after a very thorough research (Goudie et al. 1994; Pongthana et al. 1999; Dan and Little 2000; Nam et al. 2001; Kocour et al. 2005b).

The aim of the present study was to compare dressing yields in four groups of carp: (1) Hungarian mirror carp and Northern mirror carp (M2 $\times$ M72), (2) pure line of Přerov scaly carp (PS), (3) hybrid line of Přerov scaly carp and Northern mirror carp (PS $\times$ M72), and (4) a hybrid line of Přerov scaly carp and Ropsha scaly carp $(\mathrm{PS} \times \mathrm{ROP})$ in harvest size $\left(\mathrm{K}_{3}\right)$ and in relation to sex.

The study is a part of a project of comprehensive assessment of carp hybrids where, besides production variables, also quality variables (basic chemical composition, spectrum of amino acids, spectrum of fatty acids) of edible parts (muscle tissue, hard and soft roe, hepatopancreas) will be investigated.

\section{Materials and Methods}

The performance test of scaly types of the common carp started in 2001 by the fish farming company Rybníkářství Pohořelice. In the experiments, the Přerov scaly carp (PS) were used at the maternal position. These were crossed with male carp of other breeds (top crossing) namely the Prrerov scaly carp (PS) for the production of a pure line, and the Ropsha scaly carp (ROP) and the Northern mirror carp (M72). The mirror carp hybrid of the Hungarian and the Northern mirror carp $(\mathrm{M} 2 \times \mathrm{M} 72)$ were used as controls. The establishment of test populations and the test protocol were designed according to Linhart et al. (2002) and Koc our et al. (2005).

In the first test year, fry was introduced to 6 fishponds ( $0.06 \mathrm{ha}$ ), and the stocking density was 20000 fish per $0.06 \mathrm{ha}$. At an advanced fry stage (after 6 weeks), the carp were fished out, checked for weight and the stocking density was reduced to 1600 fish $/ 0.06$ ha. Because natural diet was abundant, the fry were fed limited amounts of sieved wheat meal and, exceptionally, carp feed mixture pellets (KP1). The next growth and survival check was made at the end of the vegetation period before the carp were transferred to special wintering tanks (2001).

From 2002 onward, the fish were kept in three ponds, namely the Antonín (2 700 carp/1.27 ha), Bohumír (3 400 carp/1.60 ha) and Jaroslav ponds ( $2400 \mathrm{carp} / 1.13 \mathrm{ha}$ ). These ponds are supplied with water from the Nesyt pond. No fertilizers were used in the fishponds, and two-year old grass carp were introduced there (150 grass carp per pond) to control macrophytes. For additional feeding of the fish tested, uncrushed whole wheat was used. Checks of fish weight and survival checks were always made before and after wintering period.

The performance assessment was made at the end of the 2003 vegetation period for $\mathrm{K}_{3}$ from all three fishponds (258 carp in total). A total of 15, 14 and 35 carp of each group were randomly selected from fishponds Antonín, Bohumír and Jaromír, respectively.

The fish were processed in a standard manner (Gela and Linhart 2000) in the Mušov Freshwater Fish Processing Plant of the Rybníkářství Pohořelice Comp. The dressing out was performed manually. The fish were scaled, gutted and filleted. Gonads were separated from the viscera. The head was cut off from the skeleton by a circular cut in front of the pectoral fin girdle so that the fin girdle remained at the body (Gela and Linh art 2000). Fillets were made with skin separating the flesh from spine and rib bones.

In relation to sex (female vs. male carp), attention was paid to variables important from the breeding and the yield points of view. They include biometric variables, i.e. total length (TL), standard length (SL), carcass length (CL), head length (HL), body height (BH) and body width (BW), as well as weight variables, i.e. fish weight (FW), carcass weight (CW), fillets weight, remnant weight (spine and rib bones after filleting), head weight, fins weight, gonad weight (GW), viscera weight (including hepatopancreas without gonads), hepatopancreas weight, and waste 
weight (e.g. scales, body fluid). The values obtained were used to calculate the percentages of fillets, remnant, head, fins, viscera and waste per fish weight, and important indices, e.g., the dressing percentage DP (CW: FW), index of highbackedness (IH), index of widebackedness (IW), index of head length (IHL), gonadosomatic index (GSI), hepatosomatic index (HSI) and Fulton's coefficient (FC).

Basic statistical values (means, S.D.) of the variables investigated were processed in Excel 97. Statistical significance was evaluated using the multifactorial analysis of variance (ANOVA, Statgraphics 6.0).

\section{Results}

Evaluation of dressing percentage of the control group $(\mathrm{M} 2 \times \mathrm{M} 72)$ in relation to sex (Table 1)

Table 1. Dressing percentage values for the M2 $\times$ M72 mirror control group of the common carp (Cyprinus carpio, Linnaeus 1758) in relation to sex (female, male). The model of variance analysis: multiple range test. Groups with different alphabetic superscript differ significantly at the given level of probability. M72 - Northern mirror carp, M2 - Hungarian mirror carp -* Non-significantly different at $p<0.05$

\begin{tabular}{|c|c|c|c|c|}
\hline Index & Unit & $\begin{array}{c}\text { Female } \mathrm{n}=34 \\
\text { Mean } \pm \text { S.D. }\end{array}$ & $\begin{array}{c}\text { Male } n=31 \\
\text { Mean } \pm \text { S.D. }\end{array}$ & $\begin{array}{l}\text { Statistical } \\
\text { significance }\end{array}$ \\
\hline \multicolumn{5}{|c|}{ Biometric variables } \\
\hline TL & $\mathrm{mm}$ & $432 \pm 23.13$ & $420 \pm 16.91$ & $-*$ \\
\hline SL & $\mathrm{mm}$ & $366 \pm 21.85$ & $353 \pm 16.27$ & $-*$ \\
\hline $\mathrm{CL}$ & $\mathrm{mm}$ & $299 \pm 16.66$ & $290 \pm 12.71$ & -* \\
\hline $\mathrm{HL}$ & $\mathrm{mm}$ & $94 \pm 6.05$ & $90 \pm 3.76$ & $-*$ \\
\hline IHL & & $25.82 \pm 1.10$ & $25.53 \pm 1.19$ & $-*$ \\
\hline $\mathrm{BH}$ & $\mathrm{mm}$ & $135 \pm 9.92$ & $132 \pm 7.15$ & $-*$ \\
\hline $\mathrm{IH}$ & & $2.72 \pm 0.15$ & $2.68 \pm 0.15$ & -* \\
\hline $\mathrm{BW}$ & $\mathrm{mm}$ & $79 \pm 5.47$ & $78 \pm 4.61$ & -* \\
\hline IW & & $21.62 \pm 1.32$ & $22.10 \pm 1.14$ & $-*$ \\
\hline \multicolumn{5}{|c|}{ Weight variables } \\
\hline FW & $\mathrm{g}$ & $1706.18 \pm 258.11$ & $1605.32 \pm 174.89$ & $-*$ \\
\hline $\mathrm{CW}$ & $\mathrm{g}$ & $1135.91 \pm 189.22$ & $1044.55 \pm 130.40$ & $-*$ \\
\hline FilletW ${ }_{\mathrm{abs}}$ & $\mathrm{g}$ & $854.62 \pm 148.73$ & $782.23 \pm 93.67$ & $-*$ \\
\hline FilletW $_{\text {rel }}$ & $\%$ & $49.96 \pm 2.13$ & $48.69 \pm 1.58$ & $-*$ \\
\hline DP & $\%$ & $66.45 \pm 2.20$ & $64.75 \pm 1.63$ & $-*$ \\
\hline $\mathrm{FC}$ & & $3.48 \pm 0.32$ & $3.60 \pm 0.28$ & $-*$ \\
\hline \multicolumn{5}{|c|}{ Other variables } \\
\hline HeadW $_{\text {abs }}$ & $\mathrm{g}$ & $255.60 \pm 32.59$ & $233.80 \pm 23.78$ & $-*$ \\
\hline HeadW $_{\text {rel }}$ & $\%$ & $15.07 \pm 1.23$ & $14.61 \pm 0.98$ & $-*$ \\
\hline GonadW & $\mathrm{g}$ & $50.83 \pm 23.85^{\mathrm{a}}$ & $109.32 \pm 19.29^{b}$ & $p<0.01$ \\
\hline GSI & & $3.00 \pm 1.41^{\mathrm{a}}$ & $6.83 \pm 1.10^{\mathrm{b}}$ & $p<0.05$ \\
\hline RemnantW $_{\text {abs }}$ & $\mathrm{g}$ & $281.25 \pm 45.97$ & $255.24 \pm 40.04$ & $-*$ \\
\hline RemnantW $_{\text {rel }}$ & $\%$ & $16.49 \pm 1.17$ & $15.88 \pm 1.53$ & $-*$ \\
\hline FinsW $_{\text {abs }}$ & $\mathrm{g}$ & $43.71 \pm 7.39$ & $46.33 \pm 8.41$ & $-*$ \\
\hline FinsW $_{\text {rel }}$ & $\%$ & $2.60 \pm 0.53$ & $2.90 \pm 0.50$ & $-*$ \\
\hline VisceraW $_{\mathrm{abs}}$ & $\mathrm{g}$ & $184.55 \pm 34.10^{\mathrm{a}}$ & $144.95 \pm 21.95^{\mathrm{b}}$ & $p<0.05$ \\
\hline VisceraW $_{\text {rel }}$ & $\%$ & $10.81 \pm 1.03$ & $9.02 \pm 0.78$ & $-*$ \\
\hline Waste $_{\text {abs }}$ & $\mathrm{g}$ & $35.53 \pm 13.21$ & $33.29 \pm 12.50$ & $-*$ \\
\hline Waste $_{\text {rel }}$ & $\%$ & $2.07 \pm 0.68$ & $2.07 \pm 0.73$ & -* \\
\hline
\end{tabular}

\section{Biometric variables}

In relation to sex, higher values were found in female carp, but the differences were not statistically significant $(p>0.05)$. The standard length (SL) of females was non-significantly greater $(p>0.05)$ by $3.68 \%$. 
Weight variables

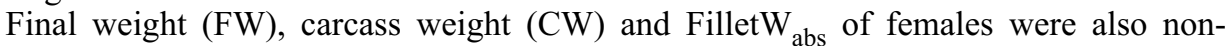
significantly $(p>0.05)$ greater by $6.28 \%, 8.75 \%$ and $9.25 \%$. Dressing percentage (DP) was higher by $2.63 \%$ in female fish $(p>0.05)$.

Other variables

In relation to sex, statistically significant differences were found in GonadW, GSI and VisceraW $\mathrm{W}_{\text {abs }}$. Testes of male fish weighed more (by 115.07\%) $(p<0.01)$, and the GSI in males was $127.67 \%$ higher $(p<0.05)$. The weight of internal organs $\left(\right.$ VisceraW $\left._{\text {abs }}\right)$ was significantly $(p<0.05)$ greater in females. Values of HeadW $\mathrm{abs}_{\text {,rel }}$ and Remnant $\mathrm{W}_{\text {abs, rel }}$ variables were nonsignificantly $(p>0.05)$ higher in females. Fins weight $\left(\right.$ Fins $\left.\mathrm{W}_{\mathrm{abs}}\right)$ and their percentage of the total bodyweight $\left(\right.$ Fins $\left.W_{\text {rel }}\right)$, however, were non-significantly $(\stackrel{p}{p}>0.05)$ greater in male carp.

\section{Evaluation of dressing percentage of the PS group in relation to sex (Table 2)}

Table 2. Dressing percentage values for the scaly pure line PS (Experimental Group 1) of the common carp (Cyprinus carpio, Linnaeus 1758) in relation to sex (female, male). The model of variance analysis: multiple range test. Groups with different alphabetic superscript differ significantly at the given level of probability. PS - Přerov scaly carp -* Non-significantly different at $p<0.05$

\begin{tabular}{|c|c|c|c|c|}
\hline Index & Unit & $\begin{array}{c}\text { Female } \mathrm{n}=38 \\
\text { Mean } \pm \text { S.D. }\end{array}$ & $\begin{array}{r}\text { Male } n=27 \\
\text { Mean } \pm \text { S.D. }\end{array}$ & $\begin{array}{c}\text { Statistical } \\
\text { significance }\end{array}$ \\
\hline \multicolumn{5}{|c|}{ Biometric variables } \\
\hline $\mathrm{TL}$ & $\mathrm{mm}$ & $399 \pm 20.90$ & $393 \pm 14.48$ & $-*$ \\
\hline $\mathrm{SL}$ & $\mathrm{mm}$ & $342 \pm 19.09$ & $336 \pm 13.33$ & -* \\
\hline $\mathrm{CL}$ & $\mathrm{mm}$ & $274 \pm 15.73$ & $270 \pm 10.24$ & _* \\
\hline $\mathrm{HL}$ & $\mathrm{mm}$ & $84 \pm 5.56$ & $81 \pm 3.59$ & _* \\
\hline IHL & & $24.41 \pm 1.15$ & $24.04 \pm 0.92$ & -** \\
\hline $\mathrm{BH}$ & $\mathrm{mm}$ & $118 \pm 7.84$ & $116 \pm 7.42$ & $-*$ \\
\hline $\mathrm{IH}$ & & $2.90 \pm 0.12$ & $2.90 \pm 0.18$ & -* \\
\hline BW & $\mathrm{mm}$ & $72 \pm 5.50$ & $71 \pm 3.88$ & -* \\
\hline IW & & $21.02 \pm 1.52$ & $21.28 \pm 1.16$ & $-*$ \\
\hline \multicolumn{5}{|c|}{ Weight variables } \\
\hline FW & $\mathrm{g}$ & $1260.66 \pm 218.51$ & $1205.93 \pm 125.36$ & _* \\
\hline $\mathrm{CW}$ & $\mathrm{g}$ & $789.76 \pm 151.75$ & $733.96 \pm 92.30$ & -* \\
\hline FilletW $\mathrm{abs}_{\mathrm{a}}$ & $\mathrm{g}$ & $580.28 \pm 114.96$ & $539.11 \pm 71.05$ & -* \\
\hline FilletW $_{\text {rel }}$ & $\%$ & $45.73 \pm 2.89$ & $44.63 \pm 2.46$ & -* \\
\hline DP & $\%$ & $62.49 \pm 2.80$ & $60.81 \pm 2.58$ & $-*$ \\
\hline $\mathrm{FC}$ & & $3.13 \pm 0.25$ & $3.18 \pm 0.27$ & $-*$ \\
\hline \multicolumn{5}{|c|}{ Other variables } \\
\hline HeadW $_{\mathrm{abs}}$ & $\mathrm{g}$ & $197.32 \pm 34.00$ & $180.89 \pm 19.57$ & $-*$ \\
\hline HeadW $_{\text {rel }}$ & $\%$ & $15.75 \pm 2.15$ & $15.08 \pm 1.69$ & $-*$ \\
\hline GonadW & $\mathrm{g}$ & $19.48 \pm 10.28^{\mathrm{a}}$ & $68.76 \pm 25.47^{\mathrm{b}}$ & $p<0.01$ \\
\hline GSI & & $1.57 \pm 0.86^{\mathrm{a}}$ & $5.75 \pm 2.08^{\mathrm{b}}$ & $p<0.05$ \\
\hline RemnantW $_{\mathrm{abs}}$ & $\mathrm{g}$ & $209.46 \pm 40.72$ & $194.81 \pm 28.21$ & $-*$ \\
\hline RemnantW $_{\text {rel }}$ & $\%$ & $16.61 \pm 1.24$ & $16.13 \pm 1.35$ & $-*$ \\
\hline Fins $_{\text {abs }}$ & $\mathrm{g}$ & $34.10 \pm 7.44$ & $33.83 \pm 6.28$ & $-*$ \\
\hline Fins $_{\text {rel }}$ & $\%$ & $2.71 \pm 0.34$ & $2.82 \pm 0.52$ & $-*$ \\
\hline VisceraW $_{\mathrm{abs}}$ & $\mathrm{g}$ & $148.01 \pm 36.38$ & $121.44 \pm 24.28$ & $-*$ \\
\hline VisceraW $_{\text {rel }}$ & $\%$ & $11.69 \pm 1.63$ & $10.05 \pm 1.51$ & $-*$ \\
\hline Waste $_{\text {abs }}$ & $\mathrm{g}$ & $71.95 \pm 15.49$ & $67.00 \pm 17.49$ & $-*$ \\
\hline Waste $_{\text {rel }}$ & $\%$ & $5.76 \pm 1.05$ & $5.55 \pm 1.33$ & $-*$ \\
\hline
\end{tabular}


Biometric variables

Although values of these variables were almost identical in both sexes $(p>0.05)$, they were slightly higher in females, e.g. the standard length (SL) of females was greater by $1.79 \%$.

Weight variables

Weight variables, too, were practically identical for both sexes $(p>0.05)$. Female carp were, however, slightly heavier (FW, CW and Fillet $\mathrm{W}_{\text {abs }}$ were greater by $4.54 \%, 7.60 \%$ and $7.64 \%$, respectively). Also higher, albeit non-significantly (by $2.76 \%)(p>0.05)$, was their dressing percentage (DP).

Table 3. Dressing percentage values for the scaly interbred hybrid PS $\times$ M72 (Experimental Group 2) of the common carp (Cyprinus carpio, Linnaeus 1758) in relation to sex (female, male). The model of variance analysis: multiple range test. Groups with different alphabetic superscript differ significantly at the given level of probability. PS - Přerov scaly carp, M72 - Northern mirror carp -* Non-significantly different at $p<0.05$

\begin{tabular}{|c|c|c|c|c|}
\hline Index & Unit & $\begin{array}{c}\text { Female } \mathrm{n}=37 \\
\text { Mean } \pm \text { S.D. }\end{array}$ & $\begin{array}{c}\text { Male } n=27 \\
\text { Mean } \pm \text { S.D. }\end{array}$ & $\begin{array}{c}\text { Statistical } \\
\text { significance }\end{array}$ \\
\hline \multicolumn{5}{|c|}{ Biometric variables } \\
\hline TL & $\mathrm{mm}$ & $434 \pm 24.39^{a}$ & $417 \pm 21.75^{b}$ & $p<0.05$ \\
\hline SL & $\mathrm{mm}$ & $370 \pm 22.16^{\mathrm{a}}$ & $354 \pm 20.87^{b}$ & $p<0.05$ \\
\hline $\mathrm{CL}$ & $\mathrm{mm}$ & $300 \pm 17.22$ & $288 \pm 17.55$ & $-*$ \\
\hline $\mathrm{HL}$ & $\mathrm{mm}$ & $97 \pm 6.67$ & $91 \pm 6.55$ & $-*$ \\
\hline IHL & & $26.12 \pm 0.91$ & $25.76 \pm 1.00$ & $-*$ \\
\hline $\mathrm{BH}$ & $\mathrm{mm}$ & $133 \pm 11.37$ & $131 \pm 10.32$ & $-*$ \\
\hline $\mathrm{IH}$ & & $2.78 \pm 0.14$ & $2.72 \pm 0.12$ & $-*$ \\
\hline $\mathrm{BW}$ & $\mathrm{mm}$ & $80 \pm 5.52$ & $77 \pm 5.05$ & $-*$ \\
\hline IW & & $21.57 \pm 1.40$ & $21.80 \pm 1.05$ & $-*$ \\
\hline \multicolumn{5}{|c|}{ Weight variables } \\
\hline FW & $\mathrm{g}$ & $1693.62 \pm 286.09^{b}$ & $1520.74 \pm 246.95^{\mathrm{a}}$ & $p<0.05$ \\
\hline $\mathrm{CW}$ & $\mathrm{g}$ & $1051.86 \pm 182.49^{\mathrm{b}}$ & $925.15 \pm 156.47^{\mathrm{a}}$ & $p<0.05$ \\
\hline FilletW $_{\mathrm{abs}}$ & $\mathrm{g}$ & $777.77 \pm 137.86^{\mathrm{b}}$ & $677.35 \pm 120.87^{\mathrm{a}}$ & $p<0.01$ \\
\hline FilletW $_{\text {rel }}$ & $\%$ & $45.89 \pm 1.69$ & $44.44 \pm 1.52$ & $-*$ \\
\hline DP & $\%$ & $62.09 \pm 1.65$ & $60.71 \pm 1.52$ & $-^{*}$ \\
\hline $\mathrm{FC}$ & & $3.32 \pm 0.29$ & $3.42 \pm 0.22$ & $-*$ \\
\hline \multicolumn{5}{|c|}{ Other variables } \\
\hline HeadW $_{\text {abs }}$ & $\mathrm{g}$ & $261.81 \pm 44.51^{b}$ & $221.15 \pm 35.64^{\mathrm{a}}$ & $p<0.05$ \\
\hline HeadW $_{\text {rel }}$ & $\%$ & $15.49 \pm 1.18$ & $14.59 \pm 1.01$ & $-*$ \\
\hline GonadW & $\mathrm{g}$ & $45.83 \pm 27.61^{\mathrm{a}}$ & $101.54 \pm 21.48^{b}$ & $p<0.01$ \\
\hline GSI & & $2.71 \pm 1.53^{\mathrm{a}}$ & $6.69 \pm 1.12^{b}$ & $p<0.05$ \\
\hline Remnant $_{\mathrm{abs}}$ & $\mathrm{g}$ & $274.01 \pm 47.48$ & $247.74 \pm 39.25$ & $-*$ \\
\hline RemnantW $_{\text {rel }}$ & $\%$ & $16.19 \pm 0.89$ & $16.34 \pm 1.09$ & $-^{*}$ \\
\hline Fins $_{\mathrm{abs}}$ & $\mathrm{g}$ & $45.57 \pm 7.63$ & $40.80 \pm 7.70$ & $-*$ \\
\hline FinsW $_{\text {rel }}$ & $\%$ & $2.73 \pm 0.44$ & $2.69 \pm 0.35$ & $-*$ \\
\hline VisceraW $_{\mathrm{abs}}$ & $\mathrm{g}$ & $205.70 \pm 44.75^{b}$ & $158.33 \pm 27.90^{\mathrm{a}}$ & $p<0.05$ \\
\hline VisceraW $_{\text {rel }}$ & $\%$ & $12.15 \pm 1.72$ & $10.44 \pm 0.97$ & $-^{*}$ \\
\hline Waste $_{\text {abs }}$ & $\mathrm{g}$ & $82.78 \pm 26.61$ & $73.70 \pm 23.29$ & $-^{*}$ \\
\hline Waste $_{\text {rel }}$ & $\%$ & $4.84 \pm 1.10$ & $4.82 \pm 1.19$ & $-^{*}$ \\
\hline
\end{tabular}

\section{Other variables}

Statistically significant differences in variables between the two sexes were found only in the GonadW and GSI variables. Testes of male carp weighed more by $252.98 \%(p<0.01)$, 
and the GSI in males was $266.24 \%$ higher $(p<0.05)$. Other variables were non-significantly greater in female carp $(p>0.05)$.

Evaluation of dressing percentage of the PS $\times$ M72 group in relation to sex (Table 3)

Biometric variables

Values of TL and SL variables were significantly $(p<0.05)$ higher in females than in males by $4.08 \%$ and $4.52 \%$, respectively. Values of other variables in relation to sex were nonsignificantly higher in female carp.

Weight variables

In female carp, significantly higher $(p<0.05) \mathrm{FW}$ and CW were found (by $11.37 \%$ and $13.70 \%$, respectively). Female carp fillets $\left(\right.$ FilletW $\left._{\text {abs }}\right)$ weighed more by $14.83 \%(p<0.01)$ than male carp fillets. The proportion of fillets $\left(\right.$ FilletW $\left.\mathrm{rel}_{\text {rel }}\right)$ and the dressing percentage (DP) were practically the same for both sexes $(p>0.05)$.

Other variables

Testes of male carp weighed more by $121.56 \%(p<0.01)$, and the GSI in males was $146.86 \%$ higher $(p<0.05)$. Significant $(p<0.05)$ differences were found in HeadW $\mathrm{abs}_{\text {and }}$ VisceraW $_{\mathrm{abs}}$ in the favour of female carp.

Evaluation of dressing percentage of the PS $\times$ ROP group in relation to sex (Table 4)

Biometric variables

Higher values in these variables were found for females, but the difference from males was non-significant $(p>0.05)$. Compared with the males, the female SL was $2.00 \%$ higher.

Weight variables

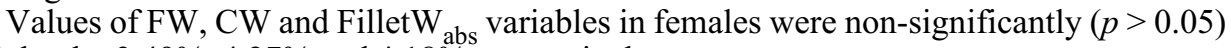
higher by $3.49 \%, 4.27 \%$ and $4.18 \%$, respectively.

Other variables

Testes of male carp weighed more by $69.13 \%(p<0.05)$, and the male GSI was $77.91 \%$ higher $(p<0.05)$. A highly significantly greater VisceraW $_{\text {abs }}$ was found for female carp $(p<0.01)$.

\section{Discussion}

The common carp (Cyprinus carpio L.) does not belong to species with a known high degree of sexual dimorphism (Baruš and Oliva 1995). This was corroborated by our experiments, in which three $(\mathrm{M} 2 \times \mathrm{M} 72$, PS, PS $\times$ ROP) out of four groups of 3-year-old carp tested demonstrated almost equal growth variables in relation to sex (Tables 1, 2, 4). Statistically significant differences in some biometric and weight variables between sexes were found in the scaly hybrid line PS $\times$ M72. Females in that group exhibited significantly higher growth rates (TL and SL by $4.08 \%$ and $4.52 \%$, respectively; $p<0.05$ ), and their weight variables were also statistically higher (FW, CW and FilletW $\mathrm{abs}_{\text {by }} 11.37 \%, 13.70 \%$ and $14.83 \%$, respectively; $p<0.05$ and $p<0.01$ ) (Table 3). Faster growth of females of the common carp was also confirmed by Cherfas et al. (1996). In their growth rate test, Gela et al. (2003) found practically identical weight for both sexes of the common carp, with the weight of females being only non-significantly greater $(p>0.05)$. In our tests, too, the weight of M2 $\times$ M72, PS and PS $\times$ ROP female carp was non-significantly greater $(p>0.05)$.

Differences in the growth rate between the two sexes in the groups studied may be related to the proven differences in the development of their gonads. Hulata et al. (1985) studied mutual relationships between sex maturation and growth rates of Chinese and European 
Table 4. Dressing percentage values for the scaly interbred hybrid PS $\times$ ROP (Experimental Group 3) of the common carp (Cyprinus carpio, Linnaeus 1758) in relation to sex (female, male). The model of variance analysis: multiple range test. Groups with different alphabetic superscript differ significantly at the given level of probability. PS - Přerov scaly carp, ROP - Ropsha scaly carp -* Non-significantly different at $p<0.050$

\begin{tabular}{|c|c|c|c|c|}
\hline Index & Unit & $\begin{array}{c}\text { Female } \mathrm{n}=30 \\
\text { Mean } \pm \text { S.D. }\end{array}$ & $\begin{array}{c}\text { Male } n=34 \\
\text { Mean } \pm \text { S.D. }\end{array}$ & $\begin{array}{c}\text { Statistical } \\
\text { significance }\end{array}$ \\
\hline \multicolumn{5}{|c|}{ Biometric variables } \\
\hline $\mathrm{TL}$ & $\mathrm{mm}$ & $478 \pm 24.44$ & $469 \pm 22.57$ & $-*$ \\
\hline SL & $\mathrm{mm}$ & $409 \pm 21.24$ & $401 \pm 22.14$ & $-*$ \\
\hline $\mathrm{CL}$ & $\mathrm{mm}$ & $331 \pm 18.69$ & $324 \pm 19.03$ & $-*$ \\
\hline $\mathrm{HL}$ & $\mathrm{mm}$ & $96 \pm 5.56$ & $93 \pm 4.75$ & $-*$ \\
\hline IHL & & $23.54 \pm 0.89$ & $23.37 \pm 1.28$ & $-*$ \\
\hline $\mathrm{BH}$ & $\mathrm{mm}$ & $134 \pm 8.80$ & $134 \pm 10.81$ & $-*$ \\
\hline IH & & $3.10 \pm 0.20$ & $3.00 \pm 0.22$ & $-*$ \\
\hline BW & $\mathrm{mm}$ & $86 \pm 5.21$ & $84 \pm 6.41$ & $-*$ \\
\hline IW & & $20.95 \pm 1.18$ & $20.99 \pm 1.19$ & $-*$ \\
\hline \multicolumn{5}{|c|}{ Weight variables } \\
\hline FW & $\mathrm{g}$ & $2052.50 \pm 297.18$ & $1983.24 \pm 346.95$ & $-*$ \\
\hline $\mathrm{CW}$ & $\mathrm{g}$ & $1314.30 \pm 207.10$ & $1260.50 \pm 248.96$ & $-*$ \\
\hline FilletW $_{\mathrm{abs}}$ & $\mathrm{g}$ & $998.57 \pm 168.60$ & $958.47 \pm 197.71$ & $-*$ \\
\hline FilletW $_{\text {rel }}$ & $\%$ & $48.50 \pm 2.02$ & $48.30 \pm 2.88$ & $-*$ \\
\hline DP & $\%$ & $63.93 \pm 1.89$ & $63.31 \pm 2.00$ & $-*$ \\
\hline FC & & $2.98 \pm 0.21$ & $3.05 \pm 0.28$ & $-*$ \\
\hline \multicolumn{5}{|c|}{ Other variables } \\
\hline HeadW ${ }_{a b s}$ & $\mathrm{~g}$ & $273.20 \pm 35.25$ & $260.59 \pm 33.41$ & $-*$ \\
\hline HeadW $_{\text {rel }}$ & $\%$ & $13.41 \pm 1.37$ & $13.29 \pm 1.29$ & $-*$ \\
\hline GonadW & $\mathrm{g}$ & $67.37 \pm 43.40^{\mathrm{a}}$ & $113.94 \pm 26.68^{b}$ & $p<0.05$ \\
\hline GSI & & $3.26 \pm 2.07^{\mathrm{a}}$ & $5.80 \pm 1.31^{\mathrm{b}}$ & $p<0.05$ \\
\hline RemnantW $_{\mathrm{abs}}$ & $\bar{g}$ & $315.72 \pm 42.58$ & $302.01 \pm 57.66$ & $-*$ \\
\hline RemnantW $_{\text {rel }}$ & $\%$ & $15.43 \pm 0.94$ & $15.23 \pm 1.13$ & $-*$ \\
\hline Fins $_{\text {abs }}$ & $\mathrm{g}$ & $54.37 \pm 10.15$ & $54.50 \pm 8.63$ & -* \\
\hline FinsW $_{\text {rel }}$ & $\%$ & $2.67 \pm 0.45$ & $2.78 \pm 0.42$ & $-*$ \\
\hline VisceraW $_{\text {abs }}$ & $\mathrm{g}$ & $234.43 \pm 45.26^{\mathrm{b}}$ & $190.62 \pm 41.23^{\mathrm{a}}$ & $p<0.01$ \\
\hline VisceraW $_{\text {rel }}$ & $\%$ & $11.43 \pm 1.60$ & $9.59 \pm 0.98$ & $-*$ \\
\hline Waste $_{\text {abs }}$ & $\mathrm{g}$ & $108.80 \pm 19.99$ & $103.06 \pm 21.71$ & $-*$ \\
\hline Waste $_{\text {rel }}$ & $\%$ & $5.30 \pm 0.63$ & $5.21 \pm 0.80$ & $-*$ \\
\hline
\end{tabular}

species of the common carp. According to him, the onset of sex maturation has a negative effect on the somatic growth rates in many fish species. The start of the production of sex hormones during sex maturation, and particularly their accumulation, inhibits the growth rate, probably as a result of an interaction between the sex and the growth hormones. In their studies on the males of the Xiphophorus maculatus species, Cohen (1946) and Kallman and Schreibman (1973) demonstrated that androgens produced by the developing testes are sex hormones particularly active in inhibiting somatic growth.

Results of our observations suggest that the onset of sex maturation comes earlier in males than in females. This finding is in agreement with the data of B aruš and Oliva (1995), who believed that male fish were, as a rule, able to first spawn a year earlier than female fish. The weight of gonads of male carp from all the groups studied was significantly higher than that of female ovaries (or, rather, the male GSI was higher). The greatest differences in the weight of gonads (GonadW) - or, rather, in GSI values - were found in the slowest growing pure 
line PS carp. The weight of male carp testes $\left(\right.$ GonadW $\left._{0^{*}}\right)$ was greater by $252.98 \%(p<0.01)$, and the GSI $o$ in that line of carp was $266.24 \%$ higher $(p<0.05)$ (Table 2$)$. Significant differences in values of those variables were found in the control group (M2 $\times$ M72 mirror carp) and PS $\times$ M72 scaly hybrids, where practically identical growth rates were ascertained. Values of GonadW ${ }_{\circ}$ and GSI ${ }_{\circ}^{*}$ for hybrids M2 $\times$ M72 were $115.07 \%(p<0.05)$ and $127.67 \%$ $(p<0.01)$ higher, respectively (Tab. 1), for hybrids PS $\times$ M72, GonadW ${ }^{*}$ and GSI ${ }^{*}$ were $121.56 \%(p<0.01)$ and $146.86 \%(p<0.05)$ higher, respectively (Table 3$)$. The least statistically significant difference in parameter values was found for PS $\times$ ROP hybrids, which showed the best results in growth rate tests (GonadWo and GSI ${ }^{*}$ were $69.13 \%(p<$ $0.05)$ and $77.91 \%(p<0.05)$ greater, respectively) (Table 4$)$. Results of the growth rate tests will be published in a separate paper (Buchtová et al. 2006).

Due to differences in the onset of sex maturation between the sexes, nutrients and energy received in feed ad libitum in males were preferentially utilized by the developing gonads, while in sexually immature or maturing females, the somatic growth was prioritized. Haffray et al. (1998) who studied growth rates of males and females of the European catfish reached similar results, but for the opposite sex. The authors found highly significant $(p<0.01)$ differences in gonads in favour of female catfish, and the final weight significantly $(p<0.05)$ greater in male catfish. The accelerated somatic growth of the males of some species of polyploid fish (Tinca tinca), when the development of female gonads is completely (and in males only partially) halted due to genome changes, is explained in a similar way (Flajšhan s et al. 1993ab).

It follows from the results of our study that statistically significant differences in specific biometric and weight variables in relation to sex were found only for the scaly hybrid PS $\times$ M72. In the overall assessment, however, the PS $\times$ M72 hybrid ranked average in growth, which was practically identical with that of the control mirror carp M2 $\times$ M72. The group that demonstrated the best growth rate in our test was the PS $\times$ ROP hybrid carp, which, however, showed no differences in the biometric or weight variables studied in relation to sex. Because females of this promising hybrid demonstrated non-significantly $(p>0.05)$ better results in the growth test than the males, it would be desirable to verify their growth variables in an all-female population test, as it has been done in the case of other hybrids tested (Kocour 2005b).

\section{Hodnocení jateční výtěžnosti 3-letých experimentálních šupinatých hybridů kapra obecného (Cyprinus carpio, Linnaeus 1758) v závislosti na pohlaví}

Cílem práce bylo porovnat užitkovou hodnotu u jikernaček a mlíčáků (závislost na pohlaví) čtyř skupin hybridních kaprů (lysý hybrid mad’arského a severského lysce: M2 $\times$ M72, čistá linie přerovského šupináče: PŠ, hybridní šupinatá linie přerovského šupináče a severského lysce: PŠ $\times$ M72, hybridní linie přerovského šupináče a ropšínského šupinatého kapra: PŠ $\times$ ROP) v tržní velikosti $\left(\mathrm{K}_{3}\right)$. Růstové schopnosti obou pohlaví čisté linie PŠ a hybridů M2 $\times$ M72 a PŠ $\times$ ROP byly prakticky stejné. Statisticky významné rozdíly některých parametrů mezi pohlavími byly zjištěny u šupinatého hybrida PŠ $\times$ M72. Samice této skupiny kaprů rostly (hodnota TL vyšší o 4.08 \%, SL vyšší o $4.52 \%$ ) průkazně $(p<0.05)$ rychleji a také hodnota jejich hmotnostních parametrů (hodnota FW vyšší o $11.37 \%$, CW vyšší o $13.70 \%$, FilletW ${ }_{\text {abs }}$ vyšší o $\left.14.83 \%\right)$ byla statisticky vyšší $(p<0.05$, resp. $p<0.01$ ). Gonády (resp. GSI) mlíčáků všech sledovaných skupin kaprů měly ve srovnání s ovárii samic vysoce signifikantně $(p<0.01)$ vyšší hmotnost (resp. vyšší hodnotu).

\section{Acknowledgments}

This experimental study was supported by the Ministry of Education, Youth and Sports of the Czech Republic (Research Plan MSM6215712402 and MSM6007665809). The authors are also grateful to all the staff of Rybnikářství Pohořelice Comp. for their kind help in processing the fish and their overall technical assistance. 


\section{References}

BARUŠ V, OLIVA O 1995: Lampryes-Petromyzontes and fishes-Osteichthyes (2). Academia Praha: 698 p.

BUCHTOVÁ H, SVOBODOVÁ Z, FLAJŠHANS M, VORLOVÁ L 2003a: Analysis of slaughtering value of diploid and triploid tench (Tinca tinca, Linnaeus 1758). Czech J Anim Sci 48: 285-294

BUCHTOVÁ H, SVOBODOVÁ Z, FLAJŠHANS M, VORLOVÁ L 2003b: Analysis of growth, weight and relevant indices of diploid and triploid population of tench (Tinca tinca, Linnaeus 1758). Aquaculture Research 34: 719-726

BUCHTOVÁ H, SVOBODOVÁ Z, KOCOUR M, VELÍŠEK J 2006: Evaluation of growth and dressing out parameters of experimental scaly crossbreds in three-year-old common carp (Cyprinus carpio, Linnaeus 1758). Aquaculture Research (in press)

CHERFAS NB, GOMELSKY B, BEN-DOM N, PERETE Y, HULATA G 1994: Assessment of triploid common carp (Cyprinus carpio L.) for culture. Aquaculture 127: 11-18

CHERFAS NB, GOMELSKY B, BEN-DOM N, JOSEPH D, COHEN S, IZRAEL I, KABESSA M, ZOHAR G, PERETE Y, MIRES D, HULATA G 1996: Assessment of all-female common carp progenies for fish culture. Israeli Journal of Aquaculture-Bamidgeh 48: 149-157

COHEN D 1946: Effects of sex hormones on the development of the platyfish, Platypoecilus maculatus. Zoologica New York 31: 121-128

DAN NC, LITTLE DC 2000: The culture performance of monosex and mixed-sex new-season and overwintered fry in three strains of Nile tilapia (Oreochronis niloticus) in northern Vietnam. Aquaculture 184 Suppl 3-4: 221231

DUDA P, GELA D, LINHART O 1999: Top-crossing with paternal inheritance testing of 4-month-old common carp Cyprinus carpio L. progeny in three altitude conditions. Aquaculture Research 30: 911-916

FLAJŚHANS M, LINHART O 2000: The production of triploid tench (in Czech). Jihočeská univerzita v Českých Budějovicích VÚRH ve Vodňanech Edice Metodik 62: $14 \mathrm{p}$.

FLAJŠHANS M 1997: Reproduction sterility caused by spontaneous triploidy in tench (Tinca tinca). Pol Arch Hydrobiol 44 Suppl 1-2: 39-45

FLAJŠHANS M, KVASNIČKA P, LINHART O 1994: Performance characteristics of artificially induced triploid carp (Cyprinus carpio L.). Bulletin VÚRH Vodňany 30 Suppl 2: 56-63

FLAJŚHANS M, KVASNIČKA P, RÁB P 1993a: Genetic studies in tench (Tinca tinca L.). A high incidence of spontaneous triploidy. Aquaculture 110: 243-248

FLAJŠHANS M, LINHART O, KVASNIČKA P 1993b: Genetic studies of tench (Tinca tinca L.): induced triploidy and tetraploidy and first performance data. Aquaculture 113: 301-312

GELA D, LINHART O 2000: Evaluation of slaughtering value of common carp from diallel crossing. Czech J Anim Sci 45: 53-58

GELA D, RODINA M, LINHART O 2003: Top-crossing with evaluation of slaughtering value in common carp (Cyprinus carpio L.) offspring. Aquaculture International 11: 379-387

GOUDIE CA, SIMCO BA, DAVIS KB, CARMICHAEL GJ 1994: Growth of channel catfish in mixed sex and monosex pond culture. Aquaculture 128: 97-104

HAFFRAY P, VAUCHEZ C, VANDEPUTTE M, LINHART O 1998: Different growth and processing traits in males and females of European catfish, Silurus glanis. Aquat Living Resour 11 Suppl 5: 341-345

HARTVICH P, FLAJŠHANS M, NÝDL V, VONDRA T, PAVLÍČEK T 2003: Growth testing of two breeds of common carps (Cyprinus carpio L.) Hungarian mirror and Trebon scaly carp, in ponds with low and high stocking density. Aquaculture Research 34: 1015-1021

HULATA G 2001: Genetic manipulations in aquaculture: a review of stock improvement by classical and modern technologies. Genetica 111: 155-173

HULATA G, WOHLFARTH G, MOAV R 1985: Genetic differences between the Chinese and European races of the common carp, Cyprinus carpio L. IV. Effects of sexual maturation on growth patterns. J Fish Biol 26: 95-103

KALLMAN KD, SCHREIBMAN MP 1973: A sex-linked gene controlling gonadotrop differentiation and its significance in determining the age of sexual maturation and size of the platyfish, Xiphophorus maculatus (poeciliidae). Science 181: 678-680

KOCOUR M, GELA D, RODINA M, LINHART O 2005a: Testing of performance in common carp Cyprinus carpio L. under pond husbandry conditions I: top-crossing with Northern mirror carp. Aquaculture Research 36 Suppl 12: 1207-1215

KOCOUR M, LINHART O, GELA D 2003: Results of comparative growing test of all-female and bisexual population in two-year-old common carp (Cyprinus carpio L.). Aquaculture International 11: 369-378

KOCOUR M, LINHART O, GELA D, RODINA M 2005b: Growth performance of all-female and mixed-sex common carp Cyprinus carpio L. Populations in the central Europe climatic conditions. J World Aquac Soc 36: 103-113

LINHART O, GELA D, RODINA M, ŠLECHTOVÁ V, ŠLECHTA V 2002: Top-crossing with paternal inheritance testing of common carp (Cyprinus carpio L.) progeny under two altitude conditions. Aquaculture 204: $481-491$ 
MOAV R, WOHLFARTH G 1976: Two-way selection for growth rate in the common carp Cyprinus carpio L. Genetics 82: 82-101

NAM YK, CHO HJ, IM JH, CHOI GC, KIM S 2001: Production of all-female diploid and triploid far eastern catfish, Silurus asotus (Linnaeus): survival and growth performance. Aquaculture Research 32 Suppl 12: 991-997

PONGTHANA N, PENMAN DJ, BAOPRASERTKUL P, HUSSAIN MG, ISLAM MS, POWELL SF, MCANDREW BJ 1999: Monosex female production in the silver barb (Puntius gonionotus Bleeker). Aquaculture 173: 247-256 